\title{
Instrumental and/or Deliberative? A Typology of CSR Communication Tools
}

\author{
Peter Seele · Irina Lock
}

Received: 9 December 2013 / Accepted: 1 July 2014/Published online: 18 July 2014

(C) Springer Science+Business Media Dordrecht 2014

\begin{abstract}
Addressing the critique that communication activities with regard to CSR are often merely instrumental marketing or public relation tools, this paper develops a toolbox of CSR communication that takes into account a deliberative notion. We derive this toolbox classification from the political approach of CSR that is based on Habermasian discourse ethics and show that it has a communicative core. Therefore, we embed CSR communication within political CSR theory and extend it by Habermasian communication theory, particularly the four validity claims of communication. Given this communicative basis, we localize CSR communication as a main means to receive moral legitimacy within political CSR theory. A typology of CSR communication tools is advanced and substantiated by a review of case studies supporting the categories. Thus, we differentiate between instrumental and deliberative, as well as published and unpublished tools. Practical examples for the literature-derived tool categories are provided and their limitations are discussed.
\end{abstract}

Keywords CSR communication - Communicative action · Credibility · Deliberative democracy · Habermas . Legitimacy

P. Seele $(\bowtie) \cdot$ I. Lock

Institute of Marketing and Communication Management (IMCA), Faculty of Communication Sciences, USI - University of Lugano, via G. Buffi 13 (R.362), 6900 Lugano, Switzerland e-mail: peter.seele@usi.ch

I. Lock

e-mail: irina.lock@usu.ch

\section{Introduction}

The political approach to CSR [corporate social responsibility] has gained momentum within the last few years (Matten and Crane 2005; Scherer and Palazzo 2007). Scholars from this view argue that corporations in a globalized world bear not only economic, social, and environmental responsibilities, but also political responsibilities. While this notion is widely recognized and is continuously extended in academia (e.g., Crane et al. 2008; Wettstein 2010; van Oosterhout 2010; Mäkinen and Kourula 2012), it does not seem to have arrived in the operations of companies. The literature on managing corporations in a political CSR sense is still absent (BaumannPauly and Scherer 2013). This applies especially to issuesensitive subfields such as CSR communication, even though it can be regarded as one of the most important means to receive moral legitimacy, the basis of political CSR (Scherer and Palazzo 2011). In order to connect political CSR to the practical realm of corporations, we propose, on the grounds of Habermasian communication theory $(1984 ; 1996)$, a "toolbox" of CSR communication. It showcases a distinction between deliberative and instrumental tools for communicating CSR and examines their suitability as a means to achieve moral legitimacy for organizations, with the focus on companies. For instance, the CSR Web site of the car manufacturer BMW (2013) is designed in a one-way communication manner, following a stakeholder information strategy (Morsing and Schultz 2006). Rather than interacting, it emphasizes informing stakeholders about BMW's social, environmental, and political responsibilities and therefore lacks the possibility for stakeholders to engage in a dialog with the company. However, discourse is seen at the core of political CSR theory (Scherer and Palazzo 2007). Taking a contrary 
example, the bottled water company Volvic (2013) tried to actively engage in a dialog with its stakeholders through a corporate blog regarding its engagement with UNESCO in a cause-related marketing project. Reaching consensus in discourse is at the heart of political CSR theory and some CSR communication tools, such as Volvic's weblog, reflect this notion well. Others, however, fuel the critique of CSR communication being a mere marketing or public relations exercise. Given mainly instrumental campaigns, CSR communication is subject to mistrust and criticism from the side of stakeholders (Klein 2013; Balch 2013) and scholars (Illia et al. 2013; Golob et al. 2013), which partially resulted from incomparable and inconsistent CSR communication by corporations. Stakeholders therefore challenged the moral legitimacy of firms, which led to a "credibility gap" (Dando and Swift 2003) between companies and stakeholders in CSR communication. CSR is conceptualized here as recent political CSR theory (Scherer and Palazzo 2007, 2011), where corporations gain moral legitimacy by participating in deliberative discourse (in a Habermasian sense, 1984; 1996) together with political actors, NGOs, shareholders, and other stakeholders. The moral legitimacy obtained in this discourse depends on credibility as we suggest in this paper, which is achieved through ethical discourse, represented by the four Habermasian validity claims of communicative action truth, sincerity, understandability, and appropriateness and the deliberative demands of political CSR theory (open discourse, participation, transparency, accountability).

This article aims to conceptualize CSR communication within the theoretical approach of political CSR in order to find a way out of the "credibility gap" (Dando and Swift 2003) in CSR communication. To do so, our contribution lies in embedding CSR communication within political CSR theory and further expanding its Habermasian basis by introducing the theory of communicative action (1984) that emphasizes the communicative core of the concept. From there, we present a typology of deliberative and instrumental CSR communication tools. A short introduction on the topic of corporations' new political role is followed by a Habermasian approach to communicating CSR based on the four validity claims applied from the theory of communicative action. Then, we derive how CSR communication may be embedded within the framework of political CSR and Habermasian approaches. Afterward, we present a typology of CSR communication tools. Each type is substantiated by a number of business ethics and management case studies we identified from a review of the leading journals. Thus, every category of the toolbox is backed up by existing cases from the literature. This analysis is followed by a discussion that addresses the communicative core of political CSR and recent critique of the political-normative view. In the end, managerial implications and limitations combined with suggestions for future research are specified (Figs. 1, 2, 3).

\section{Embedding CSR Communication Within Political CSR: A Habermasian Approach}

CSR is subject to multidisciplinary debates and is often used as an umbrella concept for diverse approaches. It seems, therefore, natural that there is no largely agreed-on definition of the social responsibilities of a corporation (Wan Saiful 2006) in the pluralistic universe of CSR (Mäkinen and Kourula 2012). Given its multidisciplinary nature, it merges normative, prescriptive, and descriptive aspects (Garriga and Melé 2004). The political approach to CSR distinguishes from classical (Bowen 1953; Wallich and McGowan 1970; Carroll 1991) and instrumental CSR theories (Porter and Kramer 2006; Kotler and Lee 2005), as it "goes beyond" (Scherer and Palazzo 2011, p. 900) these. Classical theories were concerned with the "social responsibilities of the businessman" (Bowen 1953). Then, Wallich and McGowan described a "new rationale" that put together shareholders' interests with the social responsibility of the firm. Carroll $(1979,1991)$ translated this into three dimensions of corporate social performance, which was followed by the hierarchical representation of CSR in four dimensions of a pyramid (1991).

Instrumental CSR approaches advanced this line of thought and today view CSR as strategies that first and foremost aim at improving the financial position of the firm. Societal or environmental benefits are regarded rather as a byproduct. This "business case" of CSR describes a "shift from obligation to strategy" (Kotler and Lee 2005, p. 7) that is prevalent among marketing, corporate communication, and management scholars. Thus, researchers study the link between responsibility and performance (Wood 1991; Mitnick 2000; Vogel 2005), view CSR as a tool to increase sales (Sen et al. 2006) and customer loyalty and advocacy through awareness (Du et al. 2007), and foster corporate reputation and therefore firm performance (van Riel and Fombrun 2007). Furthermore, from a value chain perspective, researchers analyze in how far CSR can contribute to establishing new products and markets, increasing productivity, and helping to develop prospering local communities at corporate production sites with a focus on developed and developing national contexts (Porter and Kramer 2006, 2011).

Political CSR, on the contrary, holds that companies conduct business with a broader horizon due to emerging powerful transnational corporations and a globalized economy. Today, corporations operate in a globalized world of morality and partly substitute functions that were assigned previously to the responsibilities of nation-states. Nation- 
states lost power and their role in the globalized world; these formerly supreme actors do not provide established ethical norms any longer. Therefore, firms engage in global public policy and by that take on a "new political role" (Scherer and Palazzo 2011) as "global corporate citizens" (Matten and Crane 2005). In this view, companies conduct business in a broadened definition of responsibility and help solve public issues in cooperation with societal actors, hence stakeholders. Issues that were formerly within the regulatory scope of nationstates are now more and more dealt with by corporations through self-regulatory activities. This entails a shift from hard to soft law that is characterized by transnational regulations that result in global soft law standards (such as ISO 26000). This shift takes place in a discourse process between corporations and stakeholders (Mena and Palazzo 2012). Hence, dialog and rational communication in a setting of deliberative democracy (Habermas 1996; Young 2004; Fung 2005) are at the core of the political approach to CSR, also labeled as the "political-normative" view (Schultz et al. 2013).

This political turn evokes also new questions of (democratic) legitimating (Scherer et al. 2013b), discussing a new form of "moral" legitimacy, which "is based on moral judgments and an exchange of arguments on whether an individual, an institution, or an action can be considered socially acceptable" (Scherer and Palazzo 2011, p. 915). Moral legitimacy is gained through various strategies: Suchman (1995) suggests symbolism, co-optation, and adjusting organizational goals to stakeholders' moral expectations. In controversial industries, moral legitimacy may be built on capturing (associating with other stakeholders), or construing (produce consent through dialog) strategies, along with CSR engagement (Reast et al. 2013). Public relations scholars suggest that moral legitimacy is a main goal of issues management (Heath and Palenchar 2008) and organizational scholars hold that it is achieved through storytelling (Golant and Sillince 2007). In political CSR, moral legitimacy can be achieved through public discourse with the goal to reach a consensus between the company and society; it is consequently established and managed by a communication process, which results in the "communicative approach to legitimacy" (Scherer et al. 2013b, p. 479). As opposed to cognitive and pragmatic legitimacy, moral legitimacy is not attributed by one party to the other, but constructed in the communication process, viewing moral legitimacy as a mutual exchange between "organizational practice" and "societal expectations" (Scherer et al. 2013a, p. 263). This shift in the source of legitimacy, which ultimately affects the companies' license to operate (Donaldson and Dunfee 1999), results in heightened emphasis of the role of communication for CSR theory.

Communication that leads to moral legitimacy is characterized by a two-way communication process. CSR communication is regarded as one of the most important parts of this moral legitimization for transnational corporations. Seen in the sense of a stakeholder involvement strategy (Morsing and Schultz 2006), CSR communication may help firms achieve the requested moral legitimacy. This strategy builds on symmetric two-way communication of the company with its stakeholders, where both sides seek to understand and influence one another. It is characterized by a dialog (Johansen and Nielsen 2011), where not only the companies have certain responsibilities and rights, but stakeholders, too. Put in simple words: "while a firm affects or can affect stakeholders, stakeholders can also affect the corporation" (Fassin 2012, p. 85). Stakeholders and corporations bear reciprocal responsibilities when it comes to the relationship and communication with companies. Hence, the moral legitimacy that establishes the license to operate for companies in a globalized context is formed by an equilibrated communication process that involves other societal actors, explicitly the stakeholders (Fitch and Surma 2007).

In order to reach consensus as the goal of ethical discourse, corporations engage in an open dialog and transparently formulate their chosen arguments, based on the idea of communicative action formulated by Habermas (1984), who is well received as a scholar in business ethics (Beschorner 2006). In his theory, Habermas distinguishes between two forms of social action-strategic and communicative. While strategic action aims at success and influence, communicative action is "oriented toward reaching understanding" (Habermas 1996, p. 63) between sender and recipient in a communication process. In order for communicative action to take place, both parties may raise, redeem, and adhere to the so-called validity claims, which are the truth, sincerity, understandability, and appropriateness of communication. Truth refers to the objective truth of statements made, sincerity (or truthfulness) is explained as the subjective truth of the propositions, understandability means that the message is understandable to the parties in the discourse, and appropriateness refers to the condition that sender and recipient agree to the same social context of communication. The validity claims are "central" to the idea of communicative action (Habermas 1984, p. 10).

The set of validity claims has to underlie the discourse between senders and recipients in order to resolve the discussed issues in consensus - text deleted (50 words) An infringement of these preconditions for communicative action may lead to a lack of trust from both sides and not result in consensus. Here, a credibility crisis can occur, where the recipients', thus the company's stakeholders', expectations are not met by the companies. Viewing CSR through the lens of stakeholder expectations management (not merely meeting stakeholder demands), this crisis may lead to a "credibility gap" (Dando and Swift 2003) between the company and its stakeholders that might ultimately threaten a firm's license to operate in society. 
Fig. 1 Habermas' validity claims and the "credibility gap" in CSR communication
Fig. 2 Political CSR as a framework for CSR communication

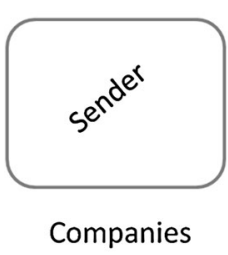

Four validity claims
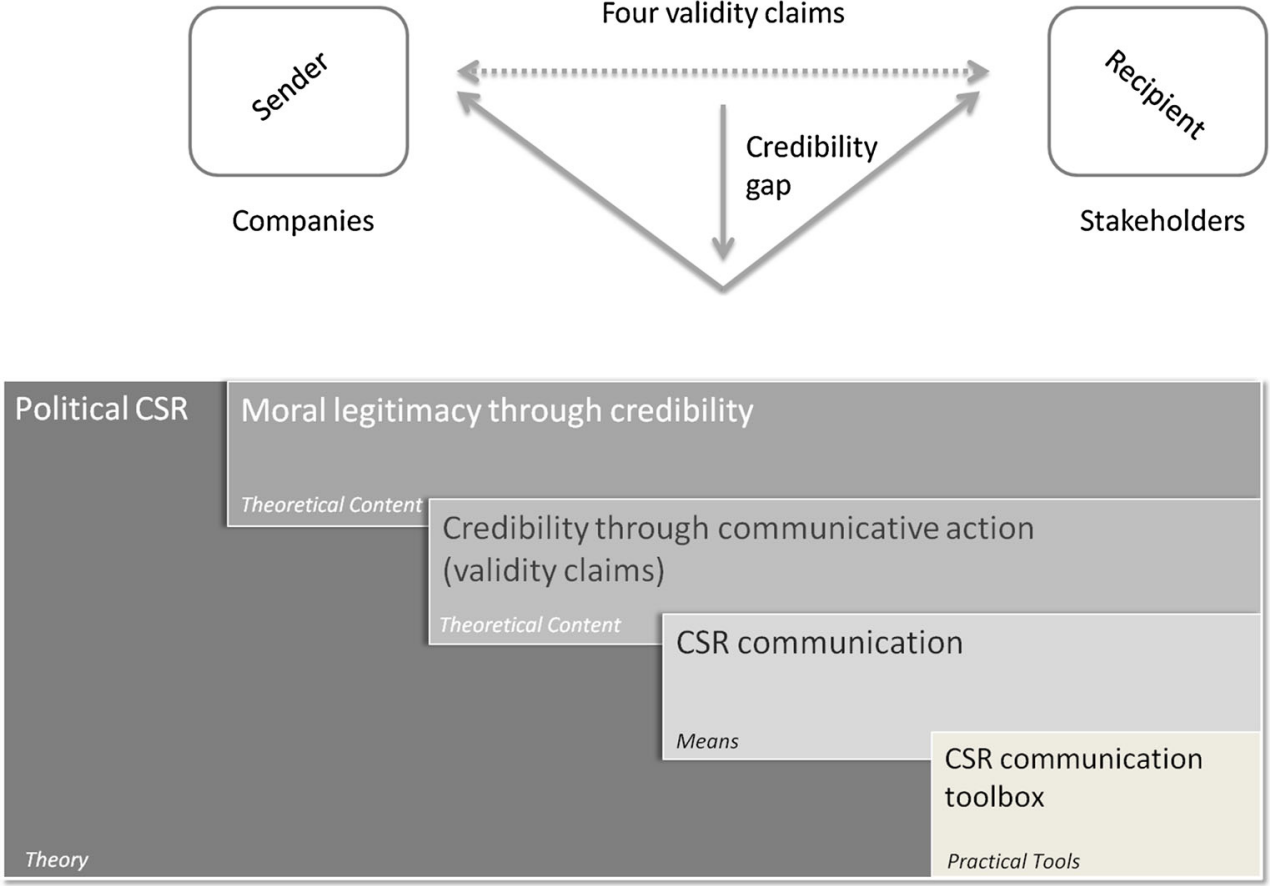

Following the Habermasian idea of communicative action, we argue that credibility in CSR communication may be re-established if companies and stakeholders engage in communicative action. Hence, if the four validity claims, truth, sincerity, appropriateness, and understandability are met by the sender as well as the recipient of CSR communication, consensus, understanding, and credibility may be reached.

Political CSR in the tradition of Habermasian discourse ethics may therefore be seen as the overarching theoretical framework, where moral legitimacy is achieved through credibility by adhering to the four validity claims in communicative action.

CSR communication is one of the most important means to convey this moral legitimacy to the outside and inside stakeholders. Despite the criticism of most CSR communication tools that is grounded on a lack of credibility and trust, several CSR communication tools meet the demands of political CSR and Habermasian communicative action.

\section{Deliberative Versus Instrumental CSR Communication Tools}

Developing a Typology Along the Literature-Derived Categories

In addition to the theory of communicative action that is rather regarded as a background concept, political CSR takes on deliberative democracy theory in order to explain the new political role of corporations. The normative demands of political CSR are referred to as open discourse, participation, transparency (Scherer and Palazzo 2007, p. 1111), and accountability (Scherer and Palazzo 2007, p. 1110), which are based on Habermasian deliberative democracy. As argued by political CSR theorists, "it seems naive to assume that all coordination problems in the context of economic activities can be solved in processes of argumentation that are oriented toward mutual understanding and agreement" (Scherer and Palazzo 2007, p. 1105). Therefore, the authors applied the theory of deliberative democracy (Habermas 1996) to the transnational corporate context. In line with the theory of communicative action, it regards deliberation and understanding between multiple societal actors in a discourse as its core. However, it does not narrowly adhere to the fulfillment criteria of the validity claims only, but rather takes on a procedural and incremental view on communicative processes (Habermas 1996).

From the very sense of the word, deliberation means consideration, discussion, and weighting of ideas with multiple actors. It implies a balance of power of actors involved and democratic will formation based on ethical discourse combined with economic bargaining (Habermas 1996). This may happen in situations "in which people organize collectively to regulate or transform some aspects of their shared social conditions, along with the communicative activities in which they try to persuade one another to join such collective actions or decide what direction they wish to take" (Young 2004, p. 377). Central to the concept is the idea of participation of multiple actors and a 
transparent two-way communication process that is "characterized by reason-giving" (Hartz-Karp and Briand, 2009, p. 127). Applying this concept to corporations means that private companies engage in democratic deliberative processes with multiple actors of society in order to resolve global public issues to reach moral legitimacy in society.

As mentioned above, CSR communication in this framework of political CSR is one of the most prominent means in this process to reach democratic legitimation in a deliberative sense. However, not all tools of CSR communication take into account this notion of deliberation, where the normative demands of open discourse, participation, transparency, and accountability on the basis of communicative action (with the four validity claims) are met. We therefore suggest a typology of CSR communication tools that includes the deliberative as well as instrumental notions of CSR and categorizes the different CSR communication tools accordingly.

When categorizing the existing tools of CSR communication, several distinctions may be drawn. Adornßent and Godemann (2011) distinguish CSR communication per communication field, resulting in risk, environmental, or science communication in order to classify the different tools. Jahdi and Acikdilli argue that a variety of tools from marketing communication may be applied to CSR communication, because they are "capable of conveying a company's CSR messages and contributing to its corporate image and brand equity" (2009, p. 106). Public relations, advertising, and sponsorship including cause-related marketing are labeled as the most effective communication instruments. Ziek (2009) takes on a communicative moves approach to CSR communication and studies the annual reports, annual shareholders letters, philanthropic information, nonfinancial reports, indexes and organizational linkages, organizational codes of conduct, and specific nonfinancial web pages as the main tools of CSR communication. Biedermann (2008), for instance, divides the tools into those directed toward internal or external audiences.

More recently, the internet as an important communication channel for CSR is recognized by many authors resulting in more and more studies on CSR web communication (e.g., Moreno and Capriotti 2009; Basil and Erlandson 2008; Chapple and Moon 2005; Chaudri and Wang 2007; Esrock and Leichty 1998; Frostenson et al. 2011; Gomez and Chalmeta 2011). Companies use the internet either unidirectionally, for instance, in the form of CSR statements on web pages (Snider et al. 2003), which is similar to offline media like printed corporate brochures, because both do not allow for responses. Or, firms engage in two-way communication on the web, fostering transparency and allowing participation and interactivity (Moreno and Capriotti 2009) that underlines the role of dialog in CSR (Golob and Podnar 2011). This second form is often found in web 2.0 applications such as social media networking platforms, blogs, or wikis. As Fieseler et al. point out (2010, p. 601), "[i]n contrast to static Web sites and reports, the development of Web 2.0 and weblogs has significant potential for engaging customers and stakeholders in a dialogue." This dialog function corresponds to the argument that CSR is "an essentially communicative challenge"(Golob et al. 2013, p. 179).

Despite the many ways researchers have attempted to categorize CSR communication, so far none has tried to provide a typology of its tools. Along with embedding CSR communication within the framework of Habermasian and political CSR theory, in this paper, we aim to categorize CSR communication tools in the "political-normative" stream of CSR (Schultz et al. 2013) along two lines, resulting in a CSR communication tool matrix. First, a distinction is drawn on the basis of CSR theory, dividing CSR communication tools into (corporate) instrumental and deliberative ones. Second, we differentiate on a corporate communication level between published and unpublished CSR communication, similar to Biedermann's (2008) distinction between internal and external tools.

\section{A Typology of CSR Communication Tools}

Supporters of instrumental CSR hold that CSR-related obligations should also support corporate objectives making strategic use of CSR to attract new customers and markets, open up market niches, increase sales, build valuable partnership, and a positive brand identity (e.g., Kotler and Lee 2005).

While the goal of deliberation is to meet the expectations of all parties involved, instrumental strategies aim to satisfy the economic needs of the company first. This teleological approach is, in our typology, applied to instrumental CSR conduct by corporations only. The categorization takes on a company perspective and does not include possible instrumental approaches to CSR communication by stakeholders.

Deliberative tools, on the contrary, follow the deliberative demands of political CSR, which are described as open discourse, participation, transparency, and accountability. Therefore, those are mostly equipped with dialogical functions in order to facilitate two-way communication. "[N]ew media are in this view regarded as instruments to gain legitimacy for corporations, as they would further improve the dialogue and engagement toward deliberative democracy and the access to conversations, hereby potentially equalizing power relations" (Schultz et al. 2013, p. 684). Hence, the internet is seen as a communication channel that facilitates the normative demands of political CSR and helps fulfill the validity claims of communicative action (Habermas 1984). 
Fig. 3 A typology of CSR communication tools

\section{Instrumental (corporate) Deliberative}

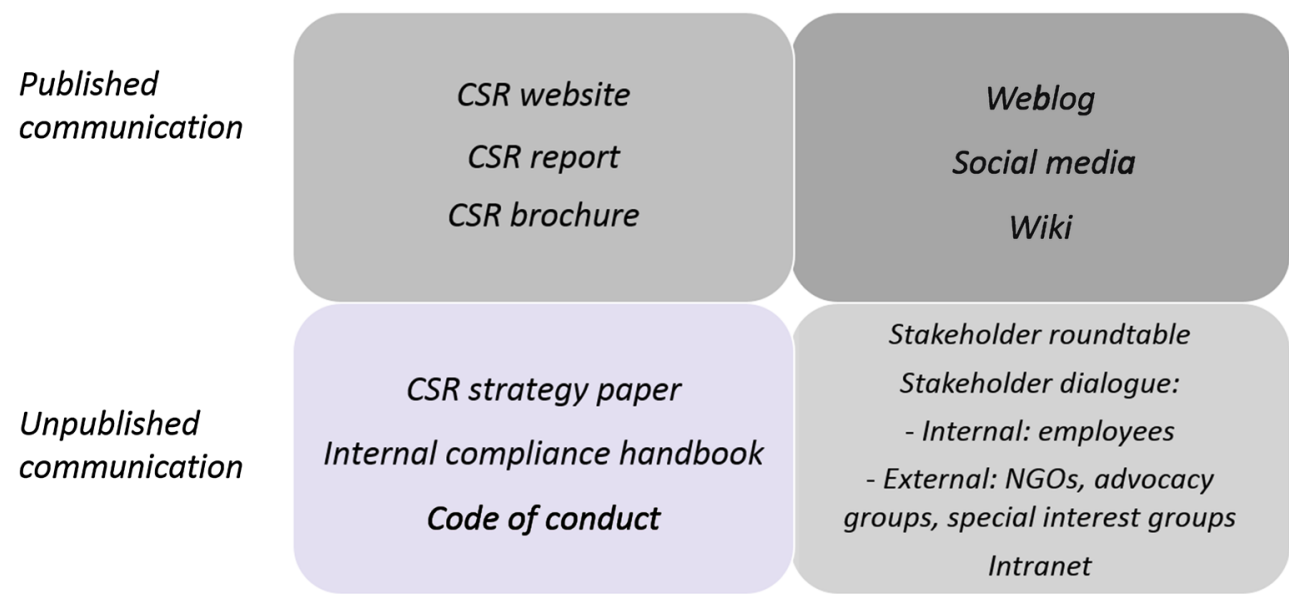

A second distinction is drawn between published and unpublished CSR material. Published implies that information is made accessible to outside stakeholders; unpublished material is usually kept within the company and often also confidential. This typology, given its roots in political CSR theory, is applied to CSR communication of large companies only. Given the myriad of tools used in corporate communication by these big businesses, we may assume that they apply more than one tool to communicate their CSR.

In the following, we describe and exemplify each type as proposed in the typology above by a series of selected case studies from business ethics, corporate communication, and general management research ${ }^{1}$. The case studies present examples and contexts describing and underpinning the suggested categories and validating the instrumental and the deliberative notion of CSR communication tools.

\section{Instrumental Published Tools}

Instrumental published tools of CSR communication refer to unidirectional CSR communication instruments that are

\footnotetext{
${ }^{1}$ We searched for case studies of CSR that deal with its communication using the terms "CSR" and "case study" in the following journals: Business Ethics Quarterly, Business Ethics: A European Review, Journal of Business Ethics, Long Range Planning, Journal of Management Studies, California Management Review, Strategic Management Journal, Sloan Management Review, Organization, Organization Science, Organization Studies, Academy of Management Journal, Academy of Management Perspectives, Academy of Management Review, Harvard Business Review, Business \& Society, Business \& Society Review, Management Communication Quarterly, Business Communication Quarterly, Corporate Communications: An International Journal. Additionally, we consulted the Business Source Premier, EconLit, and Communication \& Mass Media Complete databases with the same search terms in order to identify other relevant case studies of CSR and communication. We did not limit the search by time. After a closer examination of the relevant articles by the authors, we identified 14 relevant case studies that we included in every section of the typology chapters.
}

accessible to outside stakeholders and have a strategic corporate communication goal. Examples are CSR Web sites, nonfinancial reports, or CSR information brochures. All of these tools follow a conventional (mass) media logic, which is about informing constituents rather than actively engaging them. From a corporate communication point of view, these tools are used to "get the message across" in an informative or persuasive sense.

Classical media relations tools such as press releases fall under this category, as shown by a case study on CSR communication with vulnerable stakeholders in the extracting sector. During the time that the mining company BHP Billiton upheld a mine in Western Australia, it used several CSR communication tools to communicate with the local community-CSR reports, press releases, and a community newsletter. However, after the mine was closed, the company shut down all communication channels except for press releases. The rationale for this move was that the firm regarded press releases as the, in a contract law sense, most formal tool (Mayes et al. 2012). As this case study shows, instrumental CSR communication tools are, due to their one-way focus, easily terminable by the communicating party. Moreover, another case based on press releases between Greenpeace and sportswear companies (Brennan et al. 2013) found that the use of this tool by one party offers the possibility for the other party in the discourse to remain silent. The sports gear companies that remained silent after an NGO accused them of discharging contaminated wastewater did not experience repercussions from the audiences due to their silence, but could adapt their CSR strategies to the stakeholders' expectations in silence. In addition, press releases do not target one stakeholder group only, but speak to multiple groups at the same time. For these reasons, their potential for deliberative dialog is limited given that the discourse may be ignored, interrupted, terminated, or mediated by other players such as the media (Brennan et al. 2013). 
Furthermore, most tools of marketing communications applied to CSR would fall under the instrumental category (Jahdi and Acikdilli 2009). For instance, the sustainability strategy leaflet of the Coca Cola Company (downloadable online) depicts the company's CSR strategy in a brochure format (Coca Cola 2013). A one-way directed CSR Web site, for instance, is the one of the automobile company BMW (BMW Group 2013), where the interested reader may contact the sustainability communications team via email, but may not directly interact on the Web site. Hence, although the internet is seen as a facilitator of deliberation (Schultz et al. 2013), it is currently often not used in a deliberative way. Also in the case of oil companies this holds largely true: Most oil extractors still seem to consider the internet as a form of push rather than pull media used to receive legitimacy. The Web sites of these companies appear very accessible and some provide rich and diverse media content (Du and Vieira 2012). Deliberative engagement mechanisms for a wide array of stakeholders, however, still lack. Conoco Philips, for instance, links its social media activities to its Web site, but does not actively engage with its stakeholders on the CSR web page. However, merely linking to social media platforms does not render the CSR web page per se more deliberative. The same is true for Exxon Mobil, which, however, features a corporate blog on its Web site. Nevertheless, both companies "rather used social media platforms as another vehicle for one-way [...] communication" (Du and Vieira 2012, p. 421). Chevron, on the contrary, pursues a less instrumental path. Its CSR web page contains more interactive tools, such as a stakeholder vote on company-related issues or directly featured stakeholder stories (Du and Vieira 2012). CSR web pages and their degree of one-way communication appear to be sector- and culture-sensitive. European and US American oil companies' Web sites are easily accessible and contain much information, most of Indian IT companies, in contrast, have less than two pages of CSR information that hide behind "about us" sections. While oil companies focus on the environment and communities as their main stakeholders and neglect employees, Indian IT companies seldom mention target stakeholders at all. Moreover, also interactivity features are rare on these companies' CSR Web sites (Chaudri and Wang 2007).

Also one of CSR communication's most important means, CSR reports (Fifka 2013), are managed similarly. Although being transferred more and more in the internet, CSR reports still barely contain dialog functions, but follow a print logic. CSR reports are configured and designed as print magazines, with an opening letter from the CEO followed by articles with pictures, text boxes, etc. Integrated reports as the latest trend in CSR reporting join the annual financial with the nonfinancial report, such that the statements of the CEO in the letter addressing the stakeholders gain importance also for CSR discourse (e.g., Tengblad and Ohlsson 2010). However, the reports are instrumental tools, not deliberative in nature, as the example of the integrated CSR report of the software producer SAP, which is preset as an online report, shows: The only way to step into contact with the firm is via an investor relations email address (SAP 2012). Furthermore, also standardization of CSR reporting has not led to more deliberative application (Levy et al. 2010). An analysis of CSR reports in the Finnish forestry industry revealed that even the sustainability leaders of the sector engaged in reporting because they aimed at economic prosperity (Toppinen and Korhonen-Kurki 2013). Similarly, in the case of an Italian food company, CSR reporting is a rather technical requirement instituted by the parent company to communicate the relevant figures to the shareholders on a regular schedule (Lamberti and Lettieri 2009).

\section{Instrumental Unpublished Tools}

As instrumental unpublished tools we count, for instance, internal CSR strategy papers, compliance handbooks, or codes of conduct. These are also not deliberative, given that they do not allow for open discourse and participation. Mostly, they are strategically oriented, as evident in the case of internal strategy papers. Compliance handbooks may be published or unpublished; however, if they are directed at internal stakeholders such as employees, we regard them as unpublished tools in the sense that they are not accessible publicly. Codes of conduct have evoked a lot of research, for instance, regarding ethical behavior and performance (Adams et al. 2001; Erwin 2011; Schwartz 2004), underlying moral values (Schwartz 2005), or their strategic use by companies to impact on suppliers (Yu 2008; Sethi et al. 2011). The toy producer Mattel introduced a code of conduct as a reaction to a TV news story that featured bad working conditions at one of its suppliers and against the background of other industry's human rights scandals as in the apparel sector. As for many companies that were subject to such outcries (e.g., Nike, Reebok), the code of conduct was created internally and similarly "appeared to have been created to assuage public opinion" (Sethi et al. 2011, p. 484). The same can be observed in the case of the sportswear company Reebok that issued a code of conduct after critique by NGOs on its suppliers' working conditions (Yu 2008). Similarly, Lamberti and Lettieri (2009) describe how a company in the food industry forces its subsidiary to adopt a code of ethics in order to increase customer perceptions of product safety and health and justify a price premium. This strategic intention to create a code of conduct reflects why they may be considered instrumental CSR communication tools. 
Internal CSR communication of instrumental nature may take on various forms in different stages of CSR implementation: in the "move" and "refreezing" stage of CSR strategy implementation, Maon et al. (2009) observe especially CSR reporting, newsletters, and magazines as communication strategies that inform internal stakeholders. However, continuous and transparent stakeholder dialog is needed, which goes beyond instrumental one-way notions (see paragraph below).

\section{Deliberative Unpublished Tools}

The electronics company Philipps, for instance, uses more deliberative tools to communicate about CSR with its stakeholders internally. Buyer surveys, town hall meetings for employees, road shows for investors, or local networks for regulators are some examples of such tools. Interestingly, Philipps applies different means to different stakeholder groups in order to lower the level of stakeholder skepticism and trigger collaboration (Maon et al. 2009). Other deliberative unpublished tools are, for instance, stakeholder roundtables such as the Business Social Compliance Initiative (BSCI 2013). The organization was founded by the Foreign Trade Association in order to respond to calls for more social compliance along companies' supply chains in Europe. It is supposed to serve as a platform helping to level the playing field and monitoring different systems for social sustainability in global production networks. Participants are companies as well as associations of different kinds. Usually, the minutes of meetings of such stakeholder roundtables, where the issues, in this case regarding social compliance, are discussed, are not accessible to the public. That is why most stakeholder roundtables fall under the category of unpublished tools. However, roundtables meet many of the deliberative demands of political CSR: they happen in open discourse between the participants, are transparent (although usually only to the members), open to participation from different parties, and often the actors may be held accountable for what they state or do. Furthermore, other forms of stakeholder dialog, such as internal dialogs with employees, or external ones with NGOs, advocacy groups, or special interest groups, are also present in this category. The beer brewer Heineken, for instance, conducted an internal stakeholder dialog in the form of an interdepartmental steering committee when confronted by activists with HIV infections of local beer promoters in Cambodia. The steering group, however, applied a view that was too company-centric and therefore only had limited success. "There was no forum within which the true claims of the activist and the company could be shared" (Van Cranenburgh et al. 2013, p. 510). Examples of stakeholder dialogs that include external and internal groups are, for instance, the Forest Stewardship Council or the Global Reporting Initiative (Mena and Palazzo 2012).

Another internal deliberative CSR communication tool may be an employee hotline. The Norwegian oil company Statoil introduced such an anonymous whistle-blower telephone hotline after a scandal about one of its contracts with an Iranian oil producer. Interestingly, this hotline was installed after the scandal was resolved in order to provide for future incidents of unethical behavior. During the scandal, the company chose to inform internal and external stakeholders primarily via its CSR reporting (Vaaland and Heide 2008). This case study points to a procedural character of CSR communication, as, sometimes, deliberative CSR communication tools are employed after the limitations of instrumental tools became known.

Last, the intranet may count as an unpublished deliberative CSR communication tool. Access to the intranet is only granted to members of the company, which is why it falls under the category of unpublished tools. However, the intranet may include, besides informative web pages on CSR, also dialogical forms of online communication, such as employee blogs regarding volunteering activities, Q\&A forums concerning the environmental impact, chat rooms regarding issues such as diversity, or networking pages similar to social media applications that are linked to CSR. Depending on the structure and components of the intranet and the amount of dialogical instruments, we suggest calling it a deliberative unpublished CSR communication tool.

\section{Deliberative Published Tools}

Most online dialogical communication counts as deliberative published tools. This includes social media applications such as Twitter, wikis, or corporate blogs. Weblogs may be administered by companies only, or by firms in cooperation with stakeholders such as NGOs. In any case, "weblogs, one of the main communication platforms of the Web 2.0 era, have strong potential for engaging stakeholders on sustainability issues" (Fieseler et al. 2010, p. 601). The water producer Volvic started a blog in October 2008 with the dedicated goal to step into a dialog with its stakeholders. The blogging activities are regulated by certain "rules of the game" that Volvic openly states on the weblog. CSR activities such as the "drink one liter and donate ten" initiative that Volvic and UNICEF ran for 5 years were also communicated via the blog (Volvic 2013). But companies do not only engage in project-based blogging, but also use weblogs continuously as tools for CSR communication. McDonald's, for instance, administers a weblog where several employees blog and respond to users' comments and where the bloggers' names and job titles are visible to ensure transparency. The employee- 
bloggers comment, on average, on every second user post, which renders the blog very interactive and enables open communication between the parties. However, weblogs are not a tool for mass communication: Through weblogs, the company interacts especially with the most engaged consumers and with the opinion leaders among its stakeholders. Therefore, the spread of McDonald's blog remains rather limited to specific stakeholders (Fieseler et al. 2010).

Wikis, best represented by the most-used Web site Wikipedia, are web pages that can be edited by any user (Smith 2002, p. 256). The wiki concerning the computer firm Apple may serve as an example (www.apple.wikia. com). Here, participation and open discourse are especially emphasized, since the company cannot control who participates in the wiki in what way. Often, such wikis are started and administered not by members of the company, but by their stakeholders. These platforms for information exchange, however, may also be used for internal corporate communication in the intranet (see below).

The social media platform Twitter is used by some companies in their CSR communication. One of the pioneers in the health sector is Novo Nordisk, whose sustainability department tweets separately from the corporate communication office about issues regarding sustainability (Nordisk 2013). In general, it appears that companies such as Novo Nordisk that are already highly active in CSR also have a greater presence in social media and are more proactive when engaging with stakeholders (Lee et al. 2013). Hence, CSR leaders also benefit more from social media activity. And vice versa, CSR communication via social media increases corporate reputation (Eberle et al. 2013).

\section{Discussion}

Taking Habermas' notion of ethical discourse and the concept of deliberative democracy as background theories resulted in a two by two matrix of CSR communication tools. However, not all tools meet the deliberative demands formulated above. Instrumental CSR communication tools, be they published or unpublished, cannot, per definition, be deliberative. Deliberative unpublished tools weakly reflect one important aspect, since they are transparent only to the participants in the dialog, but not to the general public. One might argue that this is sufficient for political CSR efforts such as multistakeholder initiatives (Mena and Palazzo 2012) and even inevitable in corporate contexts, given a certain caution over publishing potentially sensitive information. On the other hand, this impacts also on the openness of the discourse to other participants. Deliberative published tools, on the contrary, account for all four deliberative demands, even though accountability in the internet might be questionable in the case of blogs or wikis, given that users can access with falsified information and nicknames. This may, however, be prevented by software programming that allows only verified users to enter the discourses.

As we posited in the beginning, CSR communication within a framework of political CSR does not only build on deliberative democracy theory, but also on the approach of Habermasian communicative action (1984). Scherer and Palazzo (2007) labeled this approach to be too utopian to be applied to the corporate world and corroborated the concept with the theory of deliberative democracy. Even if the four deliberative demands to CSR and CSR communication tools might seem somewhat idealistic on the face of them, it appears that they are quite well met by the deliberative tools of our typology. However, deliberative democracy theory builds on communicative action and the ideal speech situation with the validity claims, too. That is why we attempt to outline a Habermasian approach to CSR communication, countering the critique that political CSR is not truly "Habermasian" (Whelan 2012) and the call for more political theories to back up political CSR (Mäkinen and Kourula 2012). Even if adhering to the four validity claims truth, sincerity, appropriateness, and understandability might appear idealistic at first glance, it is not more idealistic than the presumption of the equality of power between the actors involved that is the basis of Habermasian deliberative democracy theory (1996).

We argue that, on the basis of communicative action, the four validity claims may be applied also to the deliberative tools of CSR communication in order to reach a situation of communicative rationality (Habermas 1984), where open discourse can take place that ultimately leads to moral legitimacy. Hence, statements made either in the case of published or unpublished corporate communication tools have to be objectively true, reflect the sincerity of the speakers, be appropriate in the social context, and understandable to all participants, such that deliberative CSR communication can take place.

Building on the theory of communicative action and the ideal speech situation shows that political CSR has a strong communicative core, as opposed to the critique formulated by proponents of the "communicative" view on CSR (Schultz et al. 2013). Moral legitimacy is gained through CSR communication, hence in a process of ethical discourse that might even be constitutive in nature (Schöneborn and Sandhu 2013). This is represented by certain tools of CSR communication, which are not to be regarded as equally unidirectional (Schultz et al. 2013, p. 685), but different in their theoretical setting reflected by the deliberative/instrumental classification. The "networked society" brought to light social media technologies that allow for deliberative participation and discourse, which are not under the control 
of corporations, but adhere to the validity claims of ideal speech that are presupposed from every participant.

Furthermore, we do not share the critique of a consensus bias that is attributed to political CSR, since the theory of deliberative democracy does acknowledge the polyphony of actors in legitimacy processes (Schultz et al. 2013). Consensus in Habermasian terms does not mean that all participants of a discourse have to hold the same opinions, but that multiple actors with diverse views come together to find a consensus among themselves for the public good in a discursive process (Scherer and Palazzo 2007). With the application of Habermas' theories and political CSR theory to CSR communication and the establishment of a typology of its tools, the changing role of the media based on the development regarding social connectedness is incorporated into the view of political CSR. To summarize, communication is at the core of political CSR theory through its background in discourse ethics and deliberative democracy.

\section{Limitations and Future Research}

The localization of CSR communication within political CSR theory built on Habermasian concepts represents a step forward in deepening and expanding the "political-normative" view of CSR (Schultz et al. 2013). The typology accounts for the important role of social media and classifies it within political approaches to CSR communication, which allows for recent developments in the networked society. However, embedding CSR communication within political CSR and Habermasian theories and deriving a typology from theory is subject to limitations, the prominent ones of which we want to address in the following.

\section{CSR Communication Within Political CSR}

The political approach to CSR communication is applicable predominantly to transnationally operating corporations that do business in the sphere of global governance (Scherer and Palazzo 2007). Medium and smaller sized firms cannot generally be considered actors in the global public policy arena, which is why embedding CSR communication within political CSR theory applies predominantly to transnationally operating companies. Future research might investigate roads to include also small and medium sized companies in this framework of politically responsible firms, for instance, by adopting a case study approach.

\section{Blurred Distinction Between Deliberative} and Instrumental

The intranet and CSR Web sites may be managed in an instrumental sense as indicated in the typology, but can as well adhere to a deliberative notion. This might be the case, for instance, if the intranet contains dialog functions such as weblogs or when the CSR Web site has direct dialog features such as a chat. In the typology, we decided to classify them as instrumental as today they are predominantly used in a one-way-communication fashion by most companies.

\section{Generalization}

Not only corporations, but also stakeholders can follow an instrumental approach in CSR communication. When pressuring companies to engage in multistakeholder initiatives as their CSR activity, stakeholders might do so with a strategic goal in mind. Such instrumental stakeholder behavior may surface in the realm of social media, where discourse is not controlled by either party. In this vein, future research might investigate whether stakeholders (e.g., activist groups) adopt a strategic approach to confronting corporations with specific issues on social media platforms such as twitter through computer-assisted content analysis.

\section{Time-Related Aspects}

Our typology can help analyze the status of a company's CSR communication in present, past, and future and may be the basis to judge whether the applied tools are apt to lead to moral legitimacy. It is not procedural in nature. However, it would be interesting to study if a company's experience in CSR communication is reflected in it using more deliberative or instrumental tools, as partially observed in the case of Statoil (Vaaland and Heide 2008). Future research could tackle this issue by conducting a longitudinal qualitative case study of a company's use of CSR communication tools.

\section{Empirical Verification}

Overall, in order to verify and validate our theoretically deduced CSR communication typology, it has to be tested empirically. This first attempt to classify the CSR communication tools in a political view of CSR needs future projects testing the categorization we derived from theory in a sound empirical manner. Empirical verification will also pave the way for formulating testable hypotheses regarding the toolbox of CSR communication.

Managerial Implications

As reflected by the "credibility gap", purely instrumental approaches to CSR communication do not lead to credibility and legitimacy between companies and stakeholders. 
Therefore, we would assume that a mix of deliberative and instrumental tools might constitute a good CSR communication approach. Further empirical studies might want to tackle the important question which mix of deliberative and instrumental CSR communication tools is best for communicating well with an array of stakeholders. We would suggest case study methodology as an appropriate method for investigating such issues.

\section{Cultural Distinctions}

Cultural differences are to be expected when it comes to CSR communication tools. For instance, in CSR reporting national and cultural distinctions have widely been found (for an overview see Fifka 2013). Research also shows that the nationalities of board members have an impact on the CSR conduct (and communication) of a company (e.g., Haniffa and Cooke 2005). Future research might test in how far the presented tool typology is applicable to different cultural, national, and legal contexts (see below).

\section{Legal Constraints}

We did not consider the level of regulation and legislation that, though still quite limited in the case of Europe, already affects some CSR communication tools, as, for instance, regulation on CSR reporting in Denmark (Albareda et al. 2007; Ioannou and Serafeim 2012). Therefore, we propose future research to analyze the scenario that CSR becomes more regulated by law such that deliberation may be hindered. Regarding prevailing soft law standards, the introduction of the new materiality criteria of GRI G4 (GRI 2013) is a novelty that might be considered instrumentally or deliberatively. With regard to these criteria, one could argue instrumentally and state that companies can limit their CSR scope in their own interest; or we could argue in a deliberative tradition that companies may set their CSR sphere of influence through discourse with stakeholders. Further research on the impact of the G4 guidelines on the contents of CSR reporting through content analysis might aid to shed light on this issue.

\section{Conclusions}

In this paper, we pursued two goals. First of all, we establish that the political approach to CSR is based on Habermasian discourse ethics and therefore has a strong communicative core. Therefore, we extended political CSR theory to CSR communication by Habermasian communication theory and here particularly the four validity claims of the ideal speech situation. Given this communication basis, we localized CSR communication as a main means in order to receive moral legitimacy within political CSR theory.

In consequence and secondly, we derived a typology of CSR communication tools that categorized the relevant instruments along two dimensions: instrumental and deliberative, and published and unpublished. We found that deliberative published tools of CSR communication meet the deliberative demands of political CSR theory, which are open discourse, participation, transparency, and accountability. Deliberative unpublished tools lack transparency, which also impacts on the openness of the discourse and the claim for participation. Furthermore, in order to correspond to the validity claims of communicative action, these deliberative tools have to be true, sincere, understandable, and appropriate.

Concluding, the presented typology of CSR communication tools is one small part of the bigger picture how companies may handle their responsibilities to society. The toolbox provides directions for corporations how to engage in CSR communication when following a political CSR approach of deliberation with the goal to bridge or even close the "credibility gap". The typology may guide scholars to analyze CSR communication in corporate contexts comparing for congruence or difference to the political CSR approach and hopefully provide a basis for empirical testing.

Acknowledgments The authors would like to thank Guido Palazzo for helpful comments and suggestions for developing the theoretical framework. The research for this paper was financially supported by the Swiss National Science Foundation (FSNF), grant no. 150296.

\section{References}

Adams, J. S., Tashchian, A., \& Shore, T. H. (2001). Codes of ethics as signals for ethical behavior. Journal of Business Ethics, 29, 199-211.

Adornßent, M., \& Godemann, J. (2011). Sustainability communication: An integrative approach. In J. Godemann \& G. Michelsen (Eds.), Sustainability communication (pp. 27-37). Heidelberg: Springer.

Albareda, L., Lozano, J. M., \& Ysa, T. (2007). Public policies on corporate social responsibility: The role of governments in Europe. Journal of Business Ethics, 74, 391-407.

Balch, O. (2013). Should brands better communicate their sustainability performance? The Guardian, (15th July). Accessed Sept 27, 2013, from http://www.theguardian.com/sustainable-busi ness/brands-better-communicate-sustainability-performance.

Basil, D. Z., \& Erlandson, J. (2008). Corporate Social Responsibility website representations: A longitudinal study of internal and external self-presentations. Journal of Marketing Communications, 14(2), 125-137.

Baumann-Pauly, D., \& Scherer, A. G. (2013). The organizational implementation of corporate citizenship: An assessment tool and its application at UN global compact participants. Journal of Business Ethics, 117, 1-17.

Beschorner, T. (2006). Ethical theory and business practices: The case of discourse ethics. Journal of Business Ethics, 66, 127-139. 
Biedermann, C. (2008). Corporate citizenship in der Unternehmenskommunikation. In H. Backhaus-Maul, et al. (Eds.), Corporate citizenship in Deutschland (pp. 353-370). Wiesbaden: VS Verlag.

BMW Group (2013). Responsibility. Accessed September 27, 2013, from http://www.bmwgroup.com/e/0_0_www_bmwgroup_com/ verantwortung/verantwortung_2011.html.

Bowen, H. R. (1953). Social responsibilities of the businessman. New York: Harper \& Brothers.

Brennan, N. M., Merkl-Davies, D. M., \& Beelitz, A. (2013). Dialogism in corporate social responsibility communications: conceptualising verbal interaction between organisations and their audiences. Journal of Business Ethics, 115, 665-679.

Business Social Compliance Initiative-BSCI (2013). Organization's website. Accessed September 27, 2013, from www.bsci-intl.org.

Carroll, A. B. (1979). A three-dimensional conceptual model of corporate performance. The Academy of Management Review, 4(4), 497-505.

Carroll, A. B. (1991). The pyramid of corporate social responsibility: Toward the moral management of organizational stakeholders. Business Horizons, 34(4), 39-48.

Chapple, W., \& Moon, J. (2005). Corporate social responsibility (CSR) in Asia: A seven-country study of CSR web site reporting. Business Society, 44, 415-441.

Chaudri, V., \& Wang, J. (2007). Communicating corporate social responsibility on the internet: A case study of the top 100 information technology companies in India. Management Communication Quarterly, 21(2), 232-247.

Coca Cola (2013). Sustainability at Coca Cola. Accessed September 27, 2013, from http://assets.coca-colacompany.com/a3/4b/ a3e7d93f4232a8ac16ed519cde76/sustainability-at-coca-cola-pdf. pdf.

Crane, A., Matten, D., \& Moon, J. (2008). The emergence of corporate citizenship: historical development and alternative perspectives. In A. G. Scherer \& G. Palazzo (Eds.), Handbook of research on global corporate citizenship (pp. 25-49). Cheltenham: Edward Elgar.

Dando, N., \& Swift, T. (2003). Transparency and assurance: Minding the credibility gap. Journal of Business Ethics, 44(2/3), 195-200.

Donaldson, T., \& Dunfee, T. W. (1999). Ties that bind. Boston: Harvard Business School Press.

Du, S., Bhattacharya, C. B., \& Sen, S. (2007). Reaping relational rewards from corporate social responsibility: The role of competitive positioning. International Journal of Research in Marketing, 24, 224-241.

Du, S., \& Vieira, E. T., Jr. (2012). Striving for legitimacy through corporate social responsibility: Insights from oil companies. Journal of Business Ethics, 110, 413-427.

Eberle, D., Berens, G., \& Li, T. (2013). The impact of interactive corporate social responsibility communication on corporate reputation. Journal of Business Ethics, 118, 731-746.

Erwin, P. M. (2011). Corporate codes of conduct: The effects of code content and quality on ethical performance. Journal of Business Ethics, 99, 535-548.

Esrock, S., \& Leichty, G. (1998). Social responsibility and corporate web pages: Self-presentation or agenda-setting? Public Relations Review, 24(3), 305-319.

Fassin, Y. (2012). Stakeholder management, reciprocity and stakeholder responsibility. Journal of Business Ethics, 190, 83-96.

Fieseler, C., Fleck, M., \& Meckel, M. (2010). Corporate social responsibility in the blogosphere. Journal of Business Ethics, 91, 599-614.

Fifka, M. S. (2013). Corporate responsibility reporting and its determinants in comparative perspective-A review of the empirical literature and a meta-analysis. Business Strategy and the Environment, 22, 1-35.
Fitch, K., \& Surma, A. (2007). Spin with ethics? Discourses of corporate social responsibility in Singapore and Malaysia. In: World Communication Association conference, 27-30 July, Brisbane.

Frostenson, M., Helin, S., \& Sandström, J. (2011). Organising corporate responsibility communication through filtration: A study of web communication patterns in swedish retail. Journal of Business Ethics, 100(1), 31-43.

Fung, A. (2005). Deliberation before the revolution: Toward an ethics of deliberatory democracy in an unjust world. Political Theory, 33, 397-419.

Garriga, E., \& Melé, D. (2004). Corporate social responsibility theories: mapping the territory. Journal of Business Ethics, 53, 51-71.

Global Reporting Initiativ-GRI (2013). G4 Sustainability Reporting Guidelines. Amsterdam: Global Reporting Initiative.

Golant, B. D., \& Sillince, J. A. (2007). The constitution of organizational legitimacy: A narrative perspective. Organization Studies, 28(8), 1149-1167.

Golob, U., \& Podnar, K. (2011). Corporate social responsibility communication and dialogue. In O. Ihlen, J. L. Bartlett, \& S. May (Eds.), The handbook of communication and corporate social responsibility (pp. 231-251). Chichester: Wiley.

Golob, U., Podnar, K., Elving, W. J., Nielsen, A. E., Thomsen, C., \& Schultz, F. (2013). CSR communication: quo vadis? Corporate Communications: An International Journal, 18(2), 176-192.

Gomez, L. M., \& Chalmeta, R. (2011). Corporate responsibility in U.S. corporate websites: A pilot study. Public Relations Review, 37, 93-95.

Habermas, J. (1984). The theory of communicative action. 2 vols. Boston: Beacon Press.

Habermas, J. (1996). Between facts and norms: Contributions to a discourse theory of law and democracy. Cambridge, MS: MIT Press.

Haniffa, R. M., \& Cooke, T. E. (2005). The impact of culture and governance on corporate social reporting. Journal of Accounting and Public Policy, 24(5), 391-430.

Hartz-Karp, J., \& Briand, M. K. (2009). Institutionalizing deliberative democracy. Journal of Public Affairs, 9, 125-141.

Heath, R. L., \& Palenchar, M. J. (Eds.). (2008). Strategic issues management: Organizations and public policy challenges. Thousand Oaks, CA: Sage Publications.

Illia, L., Zyglidopoulos, S. C., Romenti, S., Rodríguez-Cánovas, B., del Valle, González., \& Brena, A. (2013). Communicating corporate social responsibility to a cynical public. MIT Sloan Management Review, 54(3), 15-18.

Ioannou, I., \& Serafeim, G. (2012). The Consequences of Mandatory Corporate Sustainability Reporting. Working Paper 11-100 (26th October), Harvard Business School.

Jahdi, K. S., \& Acikdilli, G. (2009). Marketing communications and corporate social responsibility (CSR): Marriage of convenience or shotgun wedding? Journal of Business Ethics, 88, 103-113.

Johansen, T. S., \& Nielsen, A. E. (2011). Strategic stakeholder dialogues: A discursive perspective on relationship building. Corporate Communications: An International Journal, 16(3), 204-217.

Klein, P. (2013). Communicating CSR: Four Lessons from Chevron and IBM. Forbes, (14th Janurary). Accessed September 27th, 2013, from http://www.forbes.com/sites/csr/2013/01/14/commu nicating-csr-four-lessons-from-chevronand-ibm/.

Kotler, P., \& Lee, N. (2005). Corporate social responsibility. Hoboken, NJ: Wiley.

Lamberti, L., \& Lettieri, E. (2009). CSR practices and corporate strategy: Evidence from a longitudinal case study. Journal of Business Ethics, 87, 153-168.

Lee, K., Oh, W.-Y., \& Kim, N. (2013). Social media for socially responsible firms: Analysis of fortune 500's twitter profiles and 
their CSR/CSIR ratings. Journal of Business Ethics, 118, 791-806.

Levy, D., Brown, H. S., \& de Jong, M. (2010). The contested politics of corporate governance: The case of the global reporting initiative. Management and Marketing Faculty Publication Series, Paper 1. Accessed July 14, 2014, from http://scholar works.umb.edu/management_marketing_faculty_pubs/1.

Mäkinen, J., \& Kourula, A. (2012). Pluralism in political corporate social responsibility. Business Ethics Quarterly, 22(4), 649-678.

Maon, F., Lindgreen, A., \& Swaen, V. (2009). Designing and implementing corporate social responsibility: An integrative framework grounded in theory and practice. Journal of Business Ethics, 87, 71-89.

Matten, D., \& Crane, A. (2005). Corporate citizenship: Toward an extended theoretical conceptualization. Academy of Management Review, 30(1), 166-179.

Mayes, R., Pini, B., \& McDonald, P. (2012). Corporate social responsibility and the parameters of dialogue with vulnerable others. Organization, 20(6), 840-859.

Mena, S., \& Palazzo, G. (2012). Input and output legitimacy of multistakeholder initiatives. Business Ethics Quarterly, 22(3), 527-556.

Mitnick, B. M. (2000). Commitment, revelation, and the testaments of belief: The metrics of measurement of corporate social performance. Business and Society, 39(4), 419-465.

Moreno, A., \& Capriotti, P. (2009). Communicating CSR, citizenship and sustainability on the web. Journal of Communication Management, 13(2), 157-175.

Morsing, M., \& Schultz, F. (2006). Corporate social responsibility communication: Stakeholder information, response and involvement strategies. Business Ethics: A European Review, 15(4), 323-338.

Novo Nordisk (2013). Corporate website. Accessed September 27, 2013, from http://www.novonordisk.com/sustainability/default.asp.

Porter, M. E., \& Kramer, M. R. (2006). Stratgey and society. The link between competitive advantage and corporate social responsibility. Harvard Business Review, 84(12), 78-92.

Porter, M. E., \& Kramer, M. R. (2011). Creating shared value: How to reinvent capitalism and unleash a wave of innovation and growth. Harvard Business Review, 89(1-2), 1-17.

Reast, J., Maon, F., Lindgreen, A., \& Vanhamme, J. (2013). Legitimacy-seeking organizational strategies in controversial industries: A case study analysis and a bidimensional model. Journal of Business Ethics, 118(1), 139-153.

SAP (2012). SAP integrated report. Accessed September 27, 2013, from http://www.sapintegratedreport.com/2012/en/.

Scherer, A. G., Baumann-Pauly, D., \& Schneider, A. (2013a). Democratizing corporate governance: compensating for the democratic deficit of corporate political activity and corporate citizenship. Business and Society, 52(3), 473-514.

Scherer, A., \& Palazzo, G. (2007). Towards a political conception of corporate responsibility-Business and society seen from a habermasian perspective. Academy of Management Review, 32(4), 1096-1120.

Scherer, A. G., \& Palazzo, G. (2011). The new political role of business in a globalized world: A review of a new perspective on CSR and its implications for the firm, governance, and democracy. Journal of Management Studies, 48(4), 899-931.

Scherer, A. G., Palazzo, G., \& Seidl, D. (2013b). Managing Legitimacy in complex and heterogeneous environments: Sustainable development in a globalized world. Journal of Management Studies, 50(2), 259-284.

Schöneborn, D., \& Sandhu, S. (2013). When birds of different feather flock together: The emerging debate on "Organization as Communication" in the German-Speaking countries. Management Communication Quarterly, 27(2), 303-313.
Schultz, F., Morsing, M., \& Castello, I. (2013). The construction of corporate social responsibility in network societies: A communication view. Journal of Business Ethics, 115, 681-692.

Schwartz, M. S. (2004). Effective corporate codes of ethics: Perceptions of code users. Journal of Business Ethics, 55, 323-343.

Schwartz, M. S. (2005). Universal moral values for corporate codes of ethics. Journal of Business Ethics, 59, 27-44.

Sen, S., Bhattacharya, C. B., \& Korschun, D. (2006). The role of corporate social responsibility in strengthening multiple stakeholder relationships: A field experiment. Journal of the Academy of Marketing Science, 34(2), 158-166.

Sethi, S. P., Veral, E. A., Shapiro, H. J., \& Emelianova, O. (2011) Mattel Inc: Global manufacturing principles (GMP) - A lifecycle analysis of a company-based code of conduct in the toy industry. Journal of Business Ethics, 99(4), 483-517.

Smith, R. D. (2002). Strategic planning for public relations. Mahwah, NJ: Larence Erlbaum.

Snider, J., Hill, R. P., \& Martin, D. (2003). Corporate social responsibility in the 21st Century: A view from the world's most successful firms. Journal of Business Ethics, 48(2), 175-187.

Suchman, M. C. (1995). Managing legitimacy: Strategic and institutional approaches. Academy of Management Review, 20, 571-610.

Tengblad, S., \& Ohlsson, C. (2010). The framing of corporate social responsibility and the globalization of national business systems: A longitudinal case study. Journal of Business Ethics, 93, 653-669.

Toppinen, A., \& Korhonen-Kurki, K. (2013). Global Reporting Initiative and social impact in managing corporate responsibility: a case study of three multinationals in the forest industry. Business Ethics: A European Review, 22(2), 202-217.

Vaaland, T. I., \& Heide, M. (2008). Managing corporate social responsibility: Lessons from the oil industry. Corporate Communications: An International Journal, 13(2), 212-225.

Van Cranenburgh, K. C., Liket, K., \& Roome, N. (2013). Management responses to social activism in an era of corporate responsibility: A case study. Journal of Business Ethics, 118(3), 497-513.

van Oosterhout, H. J. (2010). The role of corporations in shaping the global rules of the game. In search of new foundations. Business Ethics Quarterly, 20(2), 253-264.

Van Riel, C. B., \& Fombrun, C. J. (2007). Essentials of corporate communication: Implementing practices for effective reputation management. Milton Park, UK: Routledge.

Vogel, D. J. (2005). Is there a market for virtue? The business case for corporate social responsibility. California Management Review, 47(4), 19-45.

Volvic (2013). Volvic-Blog. Accessed September 27, 2013, from http://www.volvic.de/blog/2009/08/03/volvic-fuer-unicef/.

Wallich, H. C., \& McGowan, J. J. (1970). Stockholder interest and the corporation's role in social policy. In W. J. Baumol (Ed.), A new rationale for corporate social policy. New York: Committee for Economic Development.

Wan Saiful, W.-J. (2006). Defining corporate social responsibility. Journal of Public Affairs, 6, 176-184.

Wettstein, F. (2010). For better or for worse: Corporate responsibility beyond 'Do No Harm'. Business Ethics Quarterly, 20(2), 275-283.

Whelan, G. (2012). The political perspective of corporate social responsibility: A critical research agenda. Business Ethics Quarterly, 22, 709-737.

Wood, D. J. (1991). Corporate social performance revisited. Academy of Management Review, 16(4), 691-718.

Young, I. M. (2004). Responsibility and global labor justice. Journal of Political Philosophy, 12, 365-388. 
Yu, X. (2008). Impacts of corporate code of conduct on labor standards: A case study of Reebok's athletic footwear supplier factory in China. Journal of Business Ethics, 81(3), 513-529.
Ziek, P. (2009). Making sense of CSR communication. Corporate Social Responsibility and Environmental Management, 16, 137-145. 